\title{
Hypothesis: racism is a risk factor for cerebrovascular diseases
}

I very much appreciated the editorial "Stroke in Brazil: a neglected disease", ${ }^{1}$ because it emphasized not only the high mortality rates due to cerebrovascular diseases in Brazil but also the surprising paucity of epidemiological studies that have so far investigated their determinants in our population. The editorial appropriately draws attention to the relevance of the social determinants of these conditions. I would like to suggest that the possible direct and indirect effects of racial discrimination in Brazil should be an issue for empirical investigation as potential determinants of cerebrovascular diseases. In fact, racism constitutes an additional axis of social inequalities that generate disease and deaths in our country, and has been the subject of growing academic interest. ${ }^{2}$

Recently, Chor and Lima ${ }^{3}$ reported that, differently from whites, black men and women aged 40-69 years have mortality rates from cerebrovascular diseases that are higher than from ischemic heart disease. In addition, our exploratory analyses among participants in the Pro-Saúde study in Rio de Janeiro suggested that perceived lifetime racial discrimination can increase the risk of hypertension (one major risk factor for cerebrovascular diseases), through the intervention of and/or interaction with socioeconomic adversity. These circumstances may act directly through chronic psychosocial stress and/or through more proximal etiological mechanisms in the causal chain (e.g. related to obesity).

Research on cerebrovascular diseases in Brazil should take the possible effects of racism into account at the various stages of their natural history. In multiethnic societies such as ours this may shed light both on specific societal features of ethnicity-based discrimination - a historical, ever-changing phenomenon ${ }^{5}-$ and on its potentially wide-ranging health consequences.

REFERENCES

Lotufo PA. Stroke in Brazil: a neglected disease. Sao Paulo Med J. 2005;123(1):3-4.

2. Faerstein E. Fórum: raça, racismo e saúde no Brasil. [Forum on race, racism, and health in Brazil]. Cad Saúde Pública. 2005;21(5):1584-5.

3. Chor D, Lima CRA. Aspectos epidemiológicos das desigualdades raciais em saúde no Brasil. [Epidemiologic aspects of racial inequalities in health in Brazil]. Cad Saúde Pública. 2005;21(5):1586-94.

4. Faerstein E, Chor D, Werneck G, Lopes CS, Lynch J, Kaplan G. Race and perceived racism, education, and hypertension among Brazilian civil servants (abstract). Am J Epidemiol. 2004;159(11):S35.

5. Fredrichson GM. Racism: a short history. New Jersey: Princeton University Press 2003

Sources of funding: None Conflict of interest: None

Date of first submission: November 6, 2005

Last received: June 5,2006

Accepted: August 15,

AUTHOR INFORMATIDN

Eduardo Faerstein, MD, PhD. Associate professor, Department of Epidemiology Universidade do Estado do Rio de Janeiro, Rio de Janeiro, Brazil.

Place where the manuscript was produced: Universidade do Estado do Rio de Janeiro, Rio de Janeiro, Brazil

\section{Address for correspondence:}

Rua Sacopã, 191 - Apto. 20

Rio de Janeiro (RJ) - Brasil - CEP 22471-180

Tel. (+55 21) 2587-7959

E-mail: eduardof@ueri.br 